\title{
KNOWLEDGE OF THE ORGANIZATION AND THE EFFECTIVENESS OF DECISIONS IN THE STRATEGIC DIMENSION
}

\author{
Tomasz Lis, Piotr Tomski, Małgorzata Kuraś, Piotr Kuraś
}

\author{
Czestochowa University of Technology
}

Faculty of Management

\begin{abstract}
Taking decisions is an inseparable element of running a business activity. Each employee, irrespective of the occupied post and the position in the organizational structure, takes a range of decisions every day. They influence the quality, efficiency and effectiveness of work of both themselves, the whole department and the entire enterprise. An inseparable element of decision-making is information and knowledge and it is always accompanied by risk. Possessing and obtaining information is to allow to gain knowledge whose practical use in decision-making will allow to minimize the degree of risk. Therefore, knowledge is an important factor of the efficiency of a decision and, consequently, the performance of an enterprise.

In the light of the above, the aim of the paper is to show the role which organizational knowledge plays for the efficiency of the process of decision-making in the strategic dimension. It has been assumed that decisions are acknowledged as effective if they bring about the achievement and maintenance of sustainable competitive advantage of an enterprise.
\end{abstract}

Keywords: knowledge, information, decision-making, enterprise, strategic management

DOI: $10.17512 /$ znpcz.2017.4.2.01

\section{Introduction}

Taking decisions is an inseparable element of running a business activity. Each employee, irrespective of the occupied post and the position in the organizational structure, takes a range of decisions every day. They influence the quality, efficiency and effectiveness of work of both themselves, the whole department and the entire enterprise. They are so common that they frequently do not realize the fact of their "existence". In this regard, decisions are, most of all, associated with management in the strategic area. Decision-making is preceded, among others, with: collecting and analyzing data and information, developing possible alternatives and their consequences, preparing employees, monitoring the state of preparation of an organization, monitoring micro- and macro-environment, preparing resources etc.

An inseparable element of decision-making is information and knowledge and it is always accompanied by risk. Uncertainty of decision is regarded in the literature as uncertainty of information possessed at the moment of decision-making, and also as uncertainty of the obtained results (Penc 2003, p. 182). Possessing and obtaining information is to allow to gain knowledge whose practical use in decision-making will allow to minimize the degree of risk. Therefore, knowledge is 
an important factor of the efficiency of a decision and, consequently, the performance of an enterprise.

The quality of knowledge, and also a decision depends on the amount and quality of data and information. Therefore, if an organization has access to information, which is very good with respect to quality and which is in a large amount, it achieves knowledge of a "good" quality and, consequently, decisions which are taken are always appropriate and bring about the expected results. On the other hand, if an enterprise, with respect to the problem solved, possesses only marginal amount of information, it will obtain "poor" knowledge from it, i.e. it will take decisions which carry a very high level of risk.

The aim of the paper is to show the role which organizational knowledge plays for the efficiency of the process of decision-making in the strategic dimension. It has been assumed that decisions are acknowledged as effective if they bring about the achievement and maintenance of sustainable competitive advantage of an enterprise.

\section{Decision-making in strategic management}

The managerial issues have been accompanied by the necessity of taking decisions since the beginning of the history of management of the organization. Decisions must be taken at all levels of the organization. As the Strategor (Strategor 2001, p. 413) group underline, decision-making is the least noticeable side of the enterprise policy. At the same time, it is the major driving force since, just because of this, ideas, emotions and ambitions of individuals change into strategic actions. As Brzozowska (Brzozowska 2013) underlines, operation of businesses is to a great extent determined by constant decision-making. In every organization, irrespective of the type of activity or line of business, decisions of greater or lesser importance are made, leading to the achievement of the adopted goals. Management of the decision-making process in the enterprise is one of the key elements of market activity.

According to Merriam-Webster Dictionary, "decision" is "a choice that you make about something after thinking about it: the result of deciding" (http://www.merriam-webster.com/...). A definition of "decision-making" by Zieleniewski (Zieleniewski 1976, p. 406), describes decision-making (deciding) as making a non-random choice in action. Taking a decision means the process of the selection of an action as a way of solving a specific problem. At this point, it is necessary to underline the difference between taking a decision and making selection and solving a problem. According to Huber, making selection means the limited scope of actions connected with choosing one of many possibilities. Therefore, the choice itself is a part of decision-making. On the other hand, solving the problem refers to a wide range of projects connected with searching for and implementing the direction of action leading to the correction of an unsatisfactory situation (Stoner, Wankel 1994, p. 121).

A vast literature has examined the strategic decision-making process within organizations (Brodwin, Bourgeois 1984; Bourgeois, Eisenhardt 1987). As suggested 
by Mintzberg et al. (Mintzberg, Raisinghani, Theoret 1976) "strategic simply means important, in terms of the actions taken, the resources committed, or the precedents set". This literature views strategic decision-making as a dynamic process in which many players inside the firm, acting cooperatively or independently, contribute in expected and unexpected ways to the formulation and implementation of strategy. There is a substantial body of research focused on describing and detailing decision-making as a key process of strategic management (Eisenhardt 1999; Nutt, Wilson 2010; Hart 1992). This emphasis is obvious given that strategic decisions are fundamental in shaping the success of an enterprise over the whole course of its existence (Eisenhardt, Zbaracki 1992). Strategic decision-making has emerged as one of the most active areas of current management research. The area has greatly benefited from such research traditions as behavioral decision theory and transaction cost economics and has recently gained its own momentum (Schwenk 1995).

As Shivakumar (Shivakumar 2014) underlines, strategic decisions exert a significant influence on the degree of commitment and exert a significant influence on the scope of the firm (Rotemberg, Saloner 1994). Strategic decisions are of significance because they influence the subsequent decisions - tactical and operational - that the firm must make. They are difficult to make because the problems that motivate them are often "wicked" - hard to comprehend, often without precedent, having few obviously right or wrong answers, and carrying potentially grave consequences if wrong (Rittel, Webber 1973).

Strategic decisions may also be defined as "those decisions that determine the overall direction of an enterprise and its ultimate viability in light of the unpredictable and the unknowable changes that may occur in its most important surrounding environments" (Mintzberg, Quinn 1987). The emphasis on overall direction suggests that strategic decisions must have long-term consequences. Mintzberg, Raisinghani, and Theoret (Mintzberg, Raisinghani, Theoret 1976) define a strategic decision as "one which is important in terms of the actions taken, the resources committed, or the precedents set". The reference to precedents suggests strategic decisions commit firms to some paths and make it difficult to pursue others. Eisenhardt and Zbaracki (Eisenhardt, Zbaracki 1992) describe strategic decisions as "those infrequent decisions made by the top leaders of an organization that centrally affect organizational health and survival".

In the literature there has been pointed out various dimensions/aspects of strategic-decision making (SD-making) processes. Many studies in the field of SD-making describe the process as a sequence of steps, phases or routes (Fredrickson 1984; Mintzberg, Raisinghani, Theoret 1976). Others focus on process dimensions instead (Bourgeois, Eisenhardt 1988; Hickson et al. 1986;

- $\quad$ Lyles 1987; Miller 1987). Several dimensions of SD processes can be derived from the existing literature. They include the following (Papadakis, Lioukas, Chambers 1998):

comprehensiveness/rationality dimension; elements of rationality can also be traced in studies, addressing such dimensions as complexity of methodology, degree of inquiry, and scrutiny, 
centralization,

formalization/standardization of the process,

political/problem-solving dissension dimension; this includes among others politicality, and negotiation/bargaining,

other factors have also been suggested such as dynamic factors, forcing, and duration.

Eisenhardt and Zbaracki (Eisenhardt, Zbaracki 1992) propose three dominant paradigms of strategic decision processes: rationality and bounded rationality, politics and power, and garbage can. The rational and boundedly rational paradigm is concerned with the degree to which decision makers have purposes, and describes strategic decision making as a rather purposive, systematic and comprehensive process (Allison 1971). In this process, decision makers are supposed to start with known objectives, then collect information and develop alternatives, and finally identify the optimal course of action (Simon 1955). The politics and power mode posits that the emergence, competition and resolution of conflicting interests are the essence of strategic decision processes (Baldridge 1971; Pfeffer, Salancik 1974). As decision makers harbor different and often conflicting goals in organizations, decision making often becomes a political operation whose ultimate result reflects the preference of the most powerful coalition. Finally, in the garbage can mode decision-making processes are portrayed as organized anarchies, in which a decision is largely dependent on chance and timing (Cohen, March, Olsen 1972). In this kind of process, decision makers do not know their objectives ex ante, but merely look around for decisions to make.

Hickson (Hickson 1987) identifies three basic modes of decision making: dual rationality, incrementalism and garbage can. The dual rationality mode posits that "decision making is a process of handling both problems and politics", so that it could be viewed as an integration of the rational mode and the political mode. Incremental decision making is a step-by-step process and the strategy is always amenable to adjustment. A series of incremental actions is adopted to ensure that "large, complex strategic problems are factored into smaller, less complex, and hence more manageable increments for implementation" (Joyce 1986). There is a need to make a distinction between logical incrementalism (Quinn 1980) and disjointed incrementalism (Lindblom 1959), the difference being in whether there is consistency among the increments towards a broad (rather than local) objective (Joyce 1986). The garbage can mode is the same one as in Eisenhardt and Zbaracki's study.

Lyles and Thomas (Lyles, Thomas 1988) list five primary modes of strategic decision making: rational, avoidance, adaptive, political and decisive. Four of these are similar to the modes identified by Hickson (Hickson 1987) and Eisenhardt and Zbaracki (Eisenhardt, Zbaracki 1992). For example, the adaptive mode is largely based on logical incrementalism, and the garbage can mode is the key constituent of the decisive mode. On the other hand, the avoidance mode (Cyert, March 1963) - which delineates strategic decision making as a systematic process aimed at maintaining the status quo - appears to be an important supplement. In essence, the 
avoidance mode is about avoiding the identification of new problems so that strategic changes can be rendered unnecessary (Janis, Mann 1977).

\section{Knowledge and decision efficiency}

Knowledge is a key factor of optimizing decisions, taken both in the operational and strategic dimension. Possessing appropriate knowledge, and also the capability of its practical use reduces the risk of failure of activities. This allows to avoid: uncertainty, complexity, confusion and ambiguity, and also activates the capability of an organization to use opportunities occurring on the market and eliminate threats. Therefore, it is one of the most important resources in a competitive fight in the changing environment (Morawski, Kobyłko 2006, p. 226).

Among the most important properties of knowledge there are listed: domination, inexhaustibility, simultaneity and nonlinearity. The first of the listed is connected with the role knowledge plays in management. Particularly, it refers to strategic management. Knowledge as a resource is not the subject to use but, on the contrary, it increases with the passage of time. This property is connected with inexhaustibility. Taking into consideration the possibility of gaining knowledge by different individuals, it happens rarely that it is possessed by the only one. Therefore, it may be used simultaneously by many organizations. It may also be used simultaneously in one company to perform many activities. This property is defined as simultaneity. The last of the indicated properties, i.e. nonlinearity is connected with the dependence of the obtained results on the possessed knowledge resources. This dependency is nonlinear. This, among others, results from the difficulty in clear identification, or even prediction of what results will be achieved. In this respect, simultaneity, which has been mentioned above, is of a great significance (Kłak 2010, p. 41).

According to another division, the properties of knowledge may include: subjectivity, transferability, setting, self-supply, impermanence and spontaneity. Knowledge, like information, may be transferred between individual people transferability. It is typical that interpretation of knowledge is an individual matter of each user. The person transferring and the one entering into possession of knowledge may "read" it in a different way. In case of the same problems, they may take different decisions on the basis of that - subjectivity. The man is a disposer and a possessor of knowledge. It is based in their competences, abilities and, eventually, in activities. It may be both of an explicit and tacit nature (Wrycza 2010, p. 457). As far as, in case of copying information, it loses its value, in case of knowledge, the process of passing and sharing it allows to strengthen its value - self-supply. Spreading knowledge is frequently dynamic- spontaneity. Impermanence means that, along with the passage of time, the value of knowledge and its usability decreases (Klug, Stein, Licht 2001, p. 21-22).

Knowledge, as a resource of an enterprise, may be classified by different criteria. One of them is the criterion of visibility. In this respect, it is possible to distinguish explicit knowledge (sometimes known as visible or formal) and tacit knowledge. The first of the listed is easy to identify, extract, record and transfer 
and, consequently, to manage (Budzisz, Urban, Wasiluk 2008, p. 19). Its visibility brings about that itself it has no strategic value. This results from the fact that each participant of the market can easily enter into its possession (Koźmiński, Jemielniak 2008 , p. 269). At the same time, it is common on the market. It does not determine the uniqueness of an organization, its offer or taken activities. The second of the selected kinds is tacit knowledge. It is invisible, difficult to identify, extract, record and spread. It is characteristic that even its disposer may not be aware of possessing it. It is simultaneously a unique resource which is difficult to copy. This causes that it is a decisive factor in the context of efficiency of decisions and market activities. However, to be used for this purpose, it must be identified, extracted, recorded in an understandable language and spread (Roberts-Witt 2003).

Knowledge in the decision-making process is not only the knowledge which strictly refers to the problem solved. It also consists of general knowledge possessing a very complex form. It is the knowledge of historical events - including knowledge resulting from solving similar tasks, knowledge of events and market phenomena taking place at present, in the past and the future, the knowledge of strengths and weaknesses of an organization etc. The knowledge strictly connected with the problem solved, plays a dominating role only in case of possibly full recognition of the "environment" of this problem (reasons, dependencies, possible consequences, alternative solutions etc.). Nowadays, however, when markets are characterized by high intensity and dynamics of changes, such a situation takes place rarely. Definitely more frequently, decisions are made on the basis of knowledge which is more or less incomplete and difficult to confirm. This results from the necessity of active use of weak signals in management - information which is not clear or not confirmed (Stabryła 2010, p. 28). This information allows to take actions before others do and, at the same time, achieve competitive advantage. However, it is connected with a high risk of the occurrence of errors, taking inappropriate and wrong decisions, i.e. deteriorating the possessed position on the market (Engelhardt, Brojak-Trzaskowska 2004, p. 42-44). Lack of knowledge dedicated to a decision must actually be supplemented with general knowledge, which has been mentioned before. It is to allow to fill the gap of knowledge, reduce uncertainty and risk. It is necessary to state clearly that the more extensive general knowledge is the higher the probability of taking appropriate decisions with possessing only the limited resources of dedicated knowledge. The value of general knowledge goes up along with an increase in: experience, capability, amount of the obtained partial information and knowledge, network of human relationships (both inside and outside an organization) etc. It is possible to state that general knowledge increases with the passage of time and "amount" of the acquired partial knowledge. It happens even in a situation when partial knowledge is no longer important for solving a problem, for which it is dedicated knowledge. This dependence confirms the previous statement according to which knowledge does not lose its value with the passage of time but, on the contrary, in the context of general knowledge, it becomes increasingly important. 


\section{Conclusions}

Decisions determine the efficiency of management. They directly affect competitive position of an enterprise. The decision-making process is very complicated and complex. Its efficiency is influenced by a range of factors. Among them there are: knowledge, capabilities and competences of employees, usability of the resources of information and knowledge gathered in database of companies, ability of employees to cooperate and function in a team etc. The level of its difficulty also increases the necessity to rely on a small amount of and difficult to confirm new information. Its source are the events taking place in the environment. In spite of a small amount and limited verification it is just the main incentive of a significant amount of decisions taken nowadays. The key to decision-making is understanding the environment and identifying and understanding weak signals. It is possible to state that these are one of the most important properties of an organization aspiring for the achievement of competitive advantage.

The presented dependence is particularly important if there is taken into consideration the fact that more and more decisions affecting the efficiency of strategic management must be taken on the basis of weak signals anyway. It takes place along with their strengthening. The necessity to take quick decisions on the basis of weak signals carries a high risk. Its elimination requires the possession of the greatest possible and the most valuable resources of general knowledge. In the view of the above, it is necessary to acknowledge that the value of knowledge decreases with the passage of time only in the operational dimension whereas it increases in the strategic one.

Taking foregoing considerations on board, the aim of the paper, at least in some points, has been achieved. On the other hand, above-mentioned subject is so complex and multidimensional, that it definitely requires further research.

\section{Literature}

Allison G.T. (1971), Essence of Decision: Explaining the Cuban Missile Crisis, Little Brown, Boston. The Anatomy of the "Living Dead", "California Management Review", Vol. 30(1), p. 143-159. DOI: $10.2307 / 41165271$

Bourgeois L.J., Eisenhardt K.M. (1988), Strategic Decision Processes in High Velocity Vol. 34(7), p. 816-835. DOI: 10.1287/mnsc.34.7.816

Brodwin D., Bourgeois L.J. (1984), Five Steps to Strategic Action, "California Management Review", Spring, No. 26(3), p. 176-190.

7. Brzozowska A. (2013), Management of Decision Making Processes in an Enterprise Decision Making Concepts and Models, [in:] Otola I. (ed.), Determinants of Modern Management Concepts in the Enterprises. Resources. Strategies. Decisions, Vysoká škola báňská - Technical University of Ostrava, Ostrava, p. 135-146.

Budzisz B., Urban W., Wasiluk A. (2008), Stymulowanie rozwoju przedsiębiorstwa, Difin, Warszawa. 
Cohen M.D., March J.G., Olsen J.P. (1972), A Garbage Can Model of Organizational Choice, "Administrative Science Quarterly", Vol. 17(1), p. 1-25. DOI: 10.2307/2392088

Cyert R.M., March J.G. (1963), A Behavioral Theory of the Firm, Prentice-Hall, Englewood Cliffs.

Eisenhardt K. (1999), Strategy as Strategic Decision Making, "Sloan Management Review", Vol. 40(3), p. 65-72.

8. Eisenhardt K., Zbaracki M. (1992), Strategic Decision Making, "Strategic Management Journal", Vol. 33, p. 17-37. DOI: 10.1002/smj.4250130904

9. $\quad$ Engelhardt J., Brojak-Trzaskowska M. (red.) (2004), Management Forum 2020. W kierunku 10. uniwersalnego modelu zarządzania, Fundacja na rzecz Uniwersytetu Szczecińskiego, Szczecin-Międzyzdroje, p. 42-44.

11. Fredrickson J.W. (1984), The Comprehensiveness of Strategic Decision Processes: Extension, Observations, Future Directions, "Academy of Management Journal", Vol. 27(3), p. 445-466. DOI: 10.2307/256039

Hart S.L. (1992), An Integrative Framework for Strategy-Making Processes, "Academy of 13. Management Review”, Vol. 17(2), p. 327-351. DOI: 10.2307/258775

Hickson D.J. (1987), Decision-Making at the Top of Organizations, "Annual Review of Sociology", Vol. 13, p. 165-192.

Hickson D.J., Wilson D.C., Cray D., Mallory G.R., Butler R.J. (1986), Top Decisions: Strategic Decision-Making in Organizations, Jossey-Bass, San Francisco. http://www.merriam-webster.com/dictionary/decision (accessed: 20.08.2017).

Janis I.L., Mann L. (1977), Decision-Making: A Psychological Analysis of Conflict, Choice and Commitment, Free Press, New York. Joyce W.F. (1986), Towards a Theory of Incrementalism, "Advances in Strategic Management", Vol. 4, p. 43-58.

Klug J., Stein W., Licht T. (2001), Knowledge Unplugged. The McKinsey \& Company Global Survey on Knowledge Management, McKinsey \& Company, Palgrave, Houndmills. Kłak M. (2010), Zarządzanie wiedza we współczesnym przedsiębiorstwie, Wydawnictwo Wyższej Szkoły Ekonomii i Prawa w Kielcach, Kielce.

Koźmiński A., Jemielniak D. (2008), Zarządzanie od podstaw, Wydawnictwa Akademickie i Profesjonalne, Warszawa.

23. Lindblom C.E. (1959), The Science of "Muddling Through", "Public Administration Review”, Vol. 19(2), p. 79-88. DOI: 10.2307/973677 Lyles M.A. (1987), Defining Strategic Problems: Subjective Criteria of Executives, "Organizational Studies", Vol. 8(3), p. 263-280. DOI: 10.1177/017084068700800304 Lyles M.A., Thomas H. (1988), Strategic Problem Formulation: Biases and Assumptions Embedded in Alternative Decision-Making Models, "Journal of Management Studies", Vol. 25(2), p. 131-145. DOI: 10.1111/j.1467-6486.1988.tb00028.x Miller D. (1987), The Structural and Environmental Correlates of Business Strategy, "Strategic Management Journal", Vol. 8(1), p. 55-76. DOI: 10.1002/smj.4250080106 Mintzberg H., Quinn J. (1987), The Strategy Process: Concepts, Context and Cases, 1st edition, Upper Saddle River, Prentice-Hall.

29. Mintzberg H., Raisinghani D., Theoret A. (1976), The Structure of 'Unstructured' Decision Processes, "Administrative Science Quarterly", Vol. 21(2), p. 245-275. DOI: 10.2307/ 2392045

Morawski M., Kobyłko G. (red.) (2006), Przedsiębiorstwo zorientowane na wiedze, Difin, Warszawa.

Nutt P., Wilson D. (2010), Handbook of Decision Making, John Wiley \& Sons, New York. 
Papadakis V.M., Lioukas S., Chambers D. (1998), Strategic Decision-Making Processes: The Role of Management and Context, "Strategic Management Journal", Vol. 19(2), p. 115-147. DOI: 10.1002/(SICI)1097-0266(199802)19:23.0.CO;2-5

Penc J. (2003), Menedżer w działaniu, sekrety prowadzenia biznesu, t. 1, C.H. Beck, Warszawa.

Pfeffer J., Salancik G.R. (1974), Organizational Decision Making as a Political Process: The Case of a University Budget, "Administrative Science Quarterly", Vol. 19, p. 135-151. DOI: $10.2307 / 2393885$

Quinn J.B. (1980), Strategies for Change, Logical Incrementalism, Irwin, Homewood.

Rittel H., Webber M. (1973), Dilemmas in a General Theory of Planning, "Policy Sciences", Vol. 4(2), p. 155-169.

Roberts-Witt S.L. (2003), Reinventing HR, "Knowledge Management", September, http://www.destinationcrm.com/Articles/CRM-News/CRM-Featured-News/ReinventingHR-to-Manage-Knowledge-45894.aspx (accessed: 05.08.2017).

Rotemberg J., Saloner G. (1994), Benefits of Narrow Business Strategies, "American Economic Review", Vol. 84(5), p. 1330-1349.

Schwenk C.R. (1995), Strategic Decision Making, "Journal of Management", Vol. 21(3), p. 471-493. DOI: 10.1016/0149-2063(95)90016-0

Shivakumar R. (2014), How to Tell which Decisions are Strategic, "California Management Review", Vol. 56(3), p. 78-97. DOI: 10.1525/cmr.2014.56.3.78

Simon H.A. (1955), A Behavioral Model of Rational Choice, "Quarterly Journal of Economics", Vol. 69(1), p. 99-118.

Stabryła A. (red.) (2010), Zarządzanie w kryzysie, Mfiles.pl, Kraków.

Stoner J.A.F., Wankel Ch. (1994), Kierowanie, PWE, Warszawa.

Strategor (2001), Zarządzanie firmą. Strategie, struktury, decyzje, tożsamość, PWE, Warszawa. Wrycza S. (2010), Informatyka ekonomiczna, podręcznik akademicki, PWE, Warszawa.

Zieleniewski J. (1976), Organizacja zespołów ludzkich. Wstęp do organizacji i kierowania, PWN, Warszawa.

\section{WIEDZA ORGANIZACJI A EFEKTYWNOŚĆ DECYZJI W WYMIARZE STRATEGICZNYM}

Streszczenie: Podejmowanie decyzji jest nieodłącznym elementem prowadzenia działalności gospodarczej. Każdy członek organizacji, niezależnie od zajmowanego stanowiska i pozycji w strukturze organizacyjnej, codziennie podejmuje szereg decyzji. Decyzje te mają wpływ na jakość i efektywność działań zarówno samych pracowników, jak i całego przedsiębiorstwa. Nieodłącznym elementem procesu decyzyjnego jest informacja i wiedza. Z procesem tym nierozerwalnie wiąże się ryzyko. Posiadanie lub umiejętność pozyskania odpowiednich informacji prowadzi do nabycia wiedzy, której praktyczne zastosowanie pozwala zminimalizować stopień ryzyka związanego z podejmowaniem decyzji. Dlatego wiedza jest ważnym elementem wpływającym na efektywność decyzji, a co się z tym wiąże - na efektywność całego przedsiębiorstwa.

Uwzględniając powyższe, celem artykułu jest ukazanie roli, jaką odgrywa wiedza organizacyjna dla skuteczności procesu decyzyjnego w wymiarze strategicznym. Założono, że decyzje uznaje się za skuteczne, jeżeli prowadzą do osiągnięcia i utrzymania trwałej przewagi konkurencyjnej przedsiębiorstwa.

Słowa kluczowe: wiedza, informacja, podejmowanie decyzji, przedsiębiorczość, zarządzanie strategiczne 